EnJourMe Vol.1, No.1, July 2016

\title{
CONTENT AND LANGUAGE INTEGRATED LEARNING IN
}

\author{
TEACHING ENGLISH AS SECOND LANGUAGE: A \\ SYSTEMATIC REVIEW OF EMPIRICALLY BASED ARTICLES
}

\author{
Malikhatul Lailiyah \\ University of Merdeka Malang \\ lailiyah.malikh@gmail.com
}

\begin{abstract}
This article provides a systematic review of the literature pertaining to the implication of Content and Language Integrated Learning (CLIL) as learning strategies in the education setting. The purpose of this systematic review was to examine existing research related to CLIL, including qualitative, quantitative, and mix-method research. The criteria used to select articles included in this review were: (a) only peer-reviewed article available on ERIC database, (b)the most recently articles that published during the time period 2013-2015, (c) their relevance to the implementation of CLIL in English as Second Language. Five articles that meet the criteria were undertaken in this research to show the application of CLIL in the teaching of English as Second Language.
\end{abstract}

Keywords:Learning strategies, Content and Language Integrated Learning (CLIL), Empirically Research

In a form of learning strategies, Ellis (1997) defines CLIL as particular approaches or techniques that learners employ to try to learn second language. There are tree kinds of learning strategies, they are: 1) Cognitive strategies dealing with the analysis, synthesis, or transformation of learning materials, 2) Metacognitive strategies dealing with planning, monitoring, and evaluating learning, and 3) Social or 
affective strategies concerning the ways in which learners choose to interact with other speakers.

In the term of CLIL, it was introduced in 1994 in Finland to describe a situation where students are taught the content and the foreign language simultaneously. Originally, CLIL came from immersion and bilingual programs in primary schools during the 1960 s to 1980 s, when learners were asked to practice foreign language skills to learn a discipline (Brinton, et al. 2011). Coyle, et al. (2010) defined CLIL as a dual-focused educational approach in which an additional language is used for the learning and teaching of both content and language. Further, CLIL refers to teaching a non-language subject using a foreign language, which then serves as a means of communication and content sharing (Binterova \& Kominkova, 2013).

Based on the research, there are some benefits of CLIL. First, the applications of CLIL have positive effect on increasing interest and motivation in the learners (Binterova \& Sulistya, 2013; Binterova \& Kominkova, 2013). Second, learning a foreign language through content provides problem solving skills and higher order thinking skills (Dourda, et al. 2014). Third, through CLIL, students are able to comprehend the content in a foreign language, and in the same time improve themselves in specific language skills and component (Dourda, et al., 2014; Vasques, 2014).

This article presents the background and history of CLIL and how they applied in the teaching learning process. This is followed by a presentation of the 
method to conduct a systematic review of the empirically based, the limitations of the review, and a result and discussion of the systematic review.

\section{METHODOLOGY}

For the purpose of the research, the author conducted electronic searches in the ERIC database, using the keywords: Content and Language Integrated Learning, Journal articles. The authorfound that using those keywords provided too many results, then the result were limited by these following criteria: (a)only peer-reviewed articles available on ERIC database, (b) the most recently articles that published during the time period 2013-2015, (c) their relevance to the implementation of CLIL in English as Second Language.

Once the database searching was complete, the author reviewed the entire results and chose appropriate articles to review further. After reading the abstract descriptions of the articles, a total of five articles met the criteria for inclusion in the research. Table 1 presents summary of the articles in the relevant research studies.

Table 1. Summary of the articles in the relevant research studies

\begin{tabular}{llll}
\hline No & \multicolumn{1}{c}{ Title (year) } & \multicolumn{1}{c}{ Methodology } & \multicolumn{1}{c}{ Focus } \\
\hline 1 & $\begin{array}{l}\text { GeoGebra Software Use Within } \\
\text { Content and Language Integrated } \\
\text { Learning Environment (2013) }\end{array}$ & The teaching \\
& & $\begin{array}{l}\text { mathematics lesson } \\
\text { presented in } \\
\text { English }\end{array}$ \\
2 & $\begin{array}{l}\text { Using Computers in Relation to } \\
\text { Learning Climate in CLIL Method } \\
\text { (2013) }\end{array}$ & Action research & $\begin{array}{l}\text { CLIL method in } \\
\text { Mathematics }\end{array}$ \\
& & & $\begin{array}{l}\text { Lesson } \\
\text { The lexical transfer }\end{array}$ \\
\hline
\end{tabular}




\begin{tabular}{|c|c|c|c|}
\hline & $\begin{array}{l}\text { Production of a CLIL Group and } \\
\text { Non-CLIL Group (2014) }\end{array}$ & & $\begin{array}{l}\text { production in } \\
\text { teaching English as } \\
\text { foreign language }\end{array}$ \\
\hline 4 & $\begin{array}{l}\text { Digtogloss and the Production of } \\
\text { Third Person }-s \text { by CLIL and } \\
\text { Mainstream EFL Learners: A } \\
\text { Comparative Study (2014) }\end{array}$ & Comparative study & $\begin{array}{l}\text { The use of a } \\
\text { specific } \\
\text { morphological } \\
\text { feature in CLIL and } \\
\text { mainstream EFL } \\
\text { learners }\end{array}$ \\
\hline 5 & $\begin{array}{l}\text { Content and Language Integrated } \\
\text { Learning through an Online Game } \\
\text { in Primary School: A case study } \\
\text { (2014) }\end{array}$ & Case study & $\begin{array}{l}\text { The design of an } \\
\text { educational } \\
\text { geography } \\
\text { computer game for } \\
\text { teaching English } \\
\text { language }\end{array}$ \\
\hline
\end{tabular}

\section{RESULT}

Table 1 presents the summary of the five research articles that met the criteria and thus included in this research.A description of the findings of each article is provided below.

Binterova and Sulistya (2013) conducted research which was bothquantitative and qualitative research method, in the teaching mathematics lesson presented in English as a foreign language. The research focused on the difference in students' learning achievement between students who are taught using the implementation of the CLIL method supported with open-source mathematics software, namely GeoGebra, and those who are taught with traditional mathematics lesson presented in mother tongue $(\mathrm{Czech})$. Participants $(N=175)$ were from three elementary school pupils in six classes of Grades 6-8. 
The result, both the qualitative and quantitative data analysis of this research, indicated thatthere was a significant difference between the taught of mathematics in the same subject matter presented in English as a foreign language supported with modern interactive technologies and the teaching of mathematics in mother tongue without the use of interactive technologies. The implementation of CLIL in teaching mathematics was more positively perceived by students. The analysis of videorecordings, observations, and questionnaires indicated that the teaching process in CLIL lessons increased students' motivation in lesson and it also showed that students were more active. Further, the interviews with the involved teachersindicated that there seems to be a noticeable change in teacher beliefs and skills in terms of the teaching process. Teachers are more creative in looking for new teaching methods to create interactive environment against teaching routine instruction.

Binterova and Kominkova (2013) presented a successful implementation of CLIL method in Mathematics lessons in elementary schools. The subject of the research was six classes of the sixth to eighth grade students

As the result of the research, the climate of learning Mathematics in English was perceived by the students more positively. The main factors were the clarity of teaching and the enthusiastic approach of teachers. The students evaluated the classes as more interesting. Besides, the teachers also perceived those classes as very attractive both for them themselves and for the students. It was caused mainly by new environment, new technologies, and new teaching methods used, thus it can be understood as a deviation from a stereotype. In addition, the students' perspective of 
seeing Mathematics changed and they could feel motivated and interested in the subject.

Vasques (2014) compared the lexical transfer production of two groups of students between CLIL and non-CLIL students in Andalusia and explained whether the difference in the production of lexical transfer errors could be attributable to a possible difference in language proficiency between both groups.

The results obtained that the CLIL group have produced fewer instances of lexical transfer errors than non-CLIL group. This is to say that, by adapted the Spanish word to the English morphology or phonology or by directly inserting the Spanish word into English, non-CLIL students tend to rely on their L1 more frequently than do CLIL students when they found a gap in their vocabulary and do not know the English word for what they wanted to say. Even the results have been in favor of CLIL students in terms of lexical transfer production and language proficiency, it caused by some weaknesses of this research, they are: (1) the differences in number of hours in the instruction of the teaching of English between CLIL and non-CLIL students, (2) this study has its limitation that is the number of small sample.

Basterrechea and Garcia Mayo(2014) conducted a comparative study in the production of a specific morphological feature, the English third person singular present tense marker $-s$, of the CLIL and mainstream EFL students. Participants $(\mathrm{N}=116)$ included the first year of post-compulsory secondary adolescent (15-16 years old) bilingual (Basque and Spanish) students from public and private school. In 
addition, those subjects was divided into two categories, fifty-four learners who had had English as a school subject in CLIL program and sixty-two learners who had had traditional EFL in their school.

In the treatment session, the CLIL $(\mathrm{N}=24)$ and mainstream $(\mathrm{N}=16)$ groups completed a digtogloss task in pairs and the rest of the subjects (CLIL, N=30, mainstream, $\mathrm{N}=46$ ) worked in individually. The task consisted in the reconstruction of a short passage dealing with a topic familiar to the learners.

The results of the production of the target feature in obligatory contexts in the digtogloss task indicate that CLIL learners obtained better results than mainstream learners. Then, the findings from the comparison of learners' production of the target from collaboratively and individually in each context revealed that the learners working collaboratively obtained better results in CLIL groups. However, based on the results, there was no difference between those collaborative and individual groups in the mainstream context. Thus, the comparison between the performance by CLIL and mainstream EFL learners in the collaborative condition was carried out, the analysis revealed that CLIL learners faced better in that condition.

Dourda, et al. (2014) investigated the use of the combination of the two teaching approaches, Game-based Learning (GBL) and CLIL through case study research method. The subjects randomly selected were seventeen students ( 9 girls and 8 boys) from age 11 to 12 years old. The subjects, who attended a Greek Public Primary School of Thessaloniki, worked in eight-week collaborative work. 
The result showed that the students' performance in the pre- and post-test in term of students' content knowledge was considerably improved. All students showed higher scores in the post-test as compared with the pre-test. Further, based on the analysis of their journals and their gaming activities, it shows that students' vocabulary was improved. The students used a lot of new and difficult words in English, and they completed the post-test without asking the meaning of questions or answer, as they did in pre-test. In term of students' reading skill, results showed that through the continuous exposure to the texts of the game students' reading skill was improved. As far as students collaboration concerned, as students worked in groups, they enhanced problem solving skills and critical thinking, and they learned to work in group and became autonomous learners.

\section{DISCUSSION}

This article aimed to highlight the empirical research of the use of CLIL in education setting. The findings indicate that students showed positive perceptions about the use of technology for their learning (Binterova\&Sulistya, 2013;Binterova\&Kominkova, 2013). Besides, the teaching process in CLIL lessons increased students' motivation in lesson and it also showed that students were more active, and interested in the subject. The use of CLIL also improved students' ability to work in group (Basterrechea \& Garcia Mayo, 2014; Dourda, et al., 2014).

The overall findings indicated that CLIL has positive impact in the teaching learning process. the results show that CLIL students obtained better result than non- 
CLIL students and students' content knowledge was considerably improved (Binterova \& Sulistya, 2013; Vasques, 2014; Basterrechea \& Garcia Mayo, 2014; Dourda, et al., 2014).

Thus, there are some limitations of this study that should be considered before making decisions about using CLIL in the classroom. First, only five articles established for the current systematic review. Second, only the most recently articles that published during the time period 2013-2015. It also necessary to know other research conducted before that.

\section{CONCLUSION}

Many researches dealing with CLIL yielded in significant impact in educational situation. Thus only five articles established for the current systematic review. All of them were published in ERIC database between the years 2013 and 2015. Used the very small sample of articles that meet the criteria of this review, it is not enough to use as evidence as the effectiveness of CLIL. Therefore, an empirically research with more numbers of sample article is needed.

\section{REFERENCES}

Basterrechea, M.,\& Garcia Mayo, M.P. (2014). Dictogloss and the Producton of the English third Person $-s$ by CLIL and Mainstream EFL Learners: A Comparative Study. IJES, 14, 77-98. Retrieved from the ERIC database.

Binterova, H.,\&Kominkova, O. (2013). Using Computers in Relation to Learning Climate in CLIL Method.ActaDidacticaNaponensia Journal, 6, 91-106. Retrieved from the ERIC database. 
Binterova, H.,\&Sulistya, M. (2013). GeoGebra Software Use Within a Content and Language Integrated Learning Environment. European Journal of Contemporary Education, 04,100-106. Retrieved from the ERIC database.

Brinton, D.M., Snow, M.A.,\&Weschem, M. (2011). Content based Second Language Instruction. Ann Arbor, MI: University of Michigan Press.

Dourda, K., Bratitsis, T., Griva, E.,\&Papadopoulou, P. (2014). Content and Language Integrated Learning through an Online Game in Primary School: A Case Study. The Electronic Journal of e-learning, 12, 243-258. Retrieved from the ERIC database.

Ellis, Rod. (1997). Second Language Acquisition. Oxford: Oxford University Press.

Vazques, B.M. (2014). Lexical Transfer in the Written Production of a CLIL Group and Non- CLIL Group.IJES, 14, 55-76. Retrieved from the ERIC database. 